First published in Informatologia, Vol. 45 No. 4, 2012.

INFO-146

Primljeno / Received: 2012-03-14
UDK: 659.3:621.397:007

Preliminary Communication/Prethodno priopćenje

10.32914/mcpr.10.2.4

\title{
TV MARKET AND TELEVIEWERS IN SLOVAKIA
}

\author{
Peter Kravcak \\ Catholic University in Ruzomberok, Ruzomberok, Slovakia
}

\begin{abstract}
In the early of nineties the dual broadcasting system in the young country in the middle of Europe enabled to develop television broadcasting to the scale of what viewers previously even had not dreamed of. Commercial television broadcasting prevailed in five and a half million country. Private broadcasting gained control of the more than forty-year-old state-owned service of TV broadcasting and sent it to the role of a statistical margin. Confidence of the first one - and later followed by other private televisions - has grown faster than the numbers of audience. Directors with the influence of legislators, unbeatable managers determined the transmission time programs from a week to week. This is termed as finding the optimal time based on audience preferences. The result is today's big television chaos for the viewers, who, as a consequence of unpredictable changes in the broadcasting of televisions cease to be interested. For many years the most viewed channel has dropped to the level of underrated rivals and the panic, which it suddenly started, make them produce more fatal changes. All in the name of the audience and excellent numbers of boxes called people meters. The same problem also faces other post-communist country, the second part of the former Czechoslovakia, the Czech Republic. The paper focuses on analysis and evaluation of Slovak television sphere (partly in comparison with the Czech), which seems, after twenty years of dual broadcasting, to gather a real media competition. But not everybody likes it.
\end{abstract}

Key words

Tv market, viewers, broadcasting

\section{Assumptions for TV competition}

Slovak TV viewers were born on November 3, 1956. Television studio Bratislava was the first in Slovakia and, after studio Prague, only the second in the former Czechoslovakia. TV market at that time included about 500 television sets $/ \mathbf{1} /$. Considering the discussion worthy fact, that nothing special happened in the popular mass media expansion in the 20th century, the audience was certainly on the maximum. At that time it was obvious, as the joy of the broadcaster only stemmed from the fact that it is able to broadcast and to fulfill the experience of the viewer to hear and to see the picture. Fortunately, advertising and marketing specialists never experienced this golden period. They appeared in the world of media, of course, much later. Television went through different milestones that we know. They also came to Slovakia. In 1970 the public television started broadcasting not only on the two channels (circuits), but also for the first time in color. And Alpine ski World Cup from the High Tatras, broadcasted live in dozens of countries around the world, contributed to the situation. Color broadcasting became ordinary three years later. In 1978, when both Czechoslovak channels were full-colored, the number of concessionaires exceeded one million inhabitants, which was one fifth of the country at that time. We do not have to 
remind the readers from the Central and Eastern Europe that Ideology was the main producer, screenwriter and director, nearly for forty years of broadcasting on the single television in the country. Prague Spring in 1968 made uncertain the preferred presentation of the state-building successes and unfailing steps of socialism. It meant for TV broadcasting the possibility of filming other than the socialist authors. Beautiful moments in life usually do not last long, Spring too. Slovak television broadcasting, respectively Slovak Television, was, for the remaining 20 years, an invisible part of people's daily lives. Television, of course, had its color broadcasting, every week a new high-quality fiction productions and Slovak and Czechoslovak television series reaching high quality and viewing. People realized that quality only after many years - right now, in the stream of sawdust purchased foreign production /2/. At that time television was necessary part of reality, not very attractive time how to fill occasional free evening, or a means of dramatic plot of Czechoslovak sportsmen. Television got known much better on November 22, 1989, when the news transmitted first serious events happening in the streets of Prague and Bratislava. Three days later, Slovak Television transmitted live stream of the meetings of the Velvet Revolution from SNP Square in Bratislava. It was a television screen that contributed significantly to the final fall of the regime with the information about the times full of tension in new democracy rising. Czechoslovak television was split. While the first channel remained common for both countries of former Czechoslovakia, the second channel received new frequencies and name. In the Czech Republic it was (CTV) and in Slovakia (S1). The Slovak Government changed in its resolution the name of the Czechoslovak television in the Slovak Socialist Republic to Slovak Television (STV). On 1 July 1991, the National Council of the Slovak Republic passed the act no. 254/1991 which determined legal basis of the Slovak Television as a public institution /3/. Slovak Television became the first public television in post-communist countries, whose creation was allowed by national legislation. In the same year the Federal Assembly (Parliament of CSFR) by Act no. 468/1991 on Radio and Television Broadcasting laid the basis for dual system of broadcasting. After thirty five years, when the television was found in the country, there was opened the possibility for the development of basic broadcasting under license.

\section{Dual broadcasting - competition of the audience starts}

It took four years to get a dual act of television broadcasting into practice /4/. In January 1995, broadcasting of the first private TV channel began (Danubius Cable TV), but it lasted only four months. Other TV channels did not become real competitors, for example, TV North which operated 14 months and also the most promising of all projects, VTV. Launched in April 1995, VTV during five years of its existence was largely the dramaturgical vegetation than the real alternative to public Slovak Television. STV was dominating on the Slovak television market in 1995; - we are still in the period of five years after the possibility of dual broadcasting. First channel audience was about $70 \%$, the second channel reached $15 \%$ following the surveys of Market \& Media \& Lifestyle /5/. From 1990 to 1996, STV changed nine directors $/ 6 /$, was struggling with financial problems and, despite the monopoly position, it operated at a loss every year. The competition appeared with the first Czech private TV channel Nova, which made dramatic changes also in the audience in our country in 1994. During the second year of broadcasting in Slovakia it reached $17 \%$ of the audience, and got dramatically close to the audience of STV 2. It should be noted that Nova is available primarily in the western half of the country; therefore the Czech commercial broadcaster had only partial impact on the recipients of the neighboring country. The audience figures were amazing despite this fact. In this, five years open situation for the commercial broadcasting, the fourth Slovak private television - Markiza comes on the market in august 1996. Professionally prepared TV with a strong foreign capital (U.S. Company CME, which was also behind the emergence of TV Nova in the Czech Republic) made a revolution in the television broadcasting. At that time we started to talk about the emergence of competition in television broadcasting in Slovakia. Compared to public Slovak Television it is a dynamic, commercial TV, which does not need a break in broadcasting, preparing regular reporting with the light elements of yellow journalism and spoken language. It can regularly offer the viewers some new movies and series production from the west, and after forty years of malnutrition on TV broadcasting, they do not need much to impress the viewers. Besides the undoubted cinema hits of that time, the Slovaks accepted 
with pleasure 10-year and older series and movies which were in Western Europe or in the U.S. broadcast known only as cult films /7/. Considering the mentioned time, an average commercial European television was launched on the Slovak market. However, the public broadcaster with a regular income from the state budget, revenues from license fees and advertising was relegated to the role of extras. "The way, how TV with a long history, rich archives, steady programming and technical know-how was knocked down, is surprising. TV left the position easily with an amateur way of response to dramatic changes. Commercial channels with regional status and the initial coverage $55-60 \%$ of the population reached, during four months, a significantly higher share on the market than STV audiences with its two nationwide channels"/8/. With the experience of Western Europe countries, we know that it took years for new commercial televisions to succeed on the market. The procedure was almost the same everywhere. Foreign film and series production was followed by news and self-production. These indicators were typical mostly for public broadcasters. The situation was different in the former Eastern bloc countries. Private TV channels succeeded immediately on the market, perhaps except Poland and Slovenia. Five months after the launch of commercial television, the viewing figures on the basis of daily continual research of STV were overwhelming: Markíza 41.5 percent, STV 1 - 22 percent and STV 2 only 7.6 percent $/ 9 /$. The growth of commercial entities and decrease of public broadcaster continued.

\section{TV Ratings}

Slovak Television was losing more and more. It lost its prime-time and News viewing figures, what is considered to be the most important for the public media. Moreover, during the year 1997, commercial Markiza (the year after its broadcasting started) achieved more than 50 percent of weekly market share.

Table no. 1 - The market share of STV television in the years $1996-2000$ /10/

\begin{tabular}{|c|c|c|c|c|c|}
\hline YV & 1996 & 1997 & 1998 & 1999 & 2000 \\
\hline STV 1 & $46,9 \%$ & $22,1 \%$ & $22 \%$ & $17,9 \%$ & $19,6 \%$ \\
\hline STV 2 & $16,3 \%$ & $7 \%$ & $6,7 \%$ & $4,4 \%$ & $5,8 \%$ \\
\hline
\end{tabular}

A similar decline in Central Europe was seen only in Hungary, where the public channel MTV 2 in 1997 was moved to satellite, which meant a drop of the share in the public broadcasting in this country from 56 to 10 percent. Other countries, i.e., public televisions of the region managed the transition to compete with commercial environment in a less painful way. We should mention at least one of the factors that caused the drop. Polarized society before the parliamentary elections in 1998 affected the media as well. As people were divided into pro Meciar's and anti-Meciar's, this political struggle started to play an important role in all media in Slovakia. While new Markiza was heading the efforts to change policy and cause Vladimir Meciar's removal from the position of prime minister, Slovak Television was his main medium. For readers who know the political scene in Central Europe there is no need to mention that. In 1998, the political decline of Vladimir Meciar began and the Slovak Television in elections lost too. But we cannot say, in terms of moral role of media to inform fairly and objectively, that all were losers. There was no objective alternative even for the viewers who could not comISSN 1333-6371 prehend it. But if we talk about emerging TV market, we have to talk about those who constitute the market. The competition between the broadcasters would not exist, if there were no spectators. Although the commercial and public sectors are different like apples and pears, they are both fruits; in this case they belong to the group of media market called television. To know your subscribers, it is necessary to be acquainted with their structure, number, habits, expectations and reactions. The more you know the more precisely you can serve them and get them on your side.

As dual broadcasting was in its infancy, Slovak television business makes its first steps in programming, i.e., creating a broadcasting structure. This business, after many years of habits without competition and without critical environment, was advised of subjective opinion of authors, rather than the relevant data resulting from the audience. The experimental method trial-anderror was the only one what worked in our country. The reason could be generalized and summed up as follows: young democratic state, no freebroadcasting experience, lack of competitive envi- 
ronment and inexperienced viewers for whom everything on television was new like America for Europeans in the 15th century. The audience measurement was available only thanks to daily continual research by STV (with its special department) and later the research by the VISIO Company, which was executed by post. In this audience measurement, the viewers filled in questionnaires that were divided into days - i.e. diary method. They had to re-remember what they had watched in particular day and hour. The time between watching and writing the questionnaire was often one week, to say nothing of the speed of re-processing results, which were sent by post. That is why there was a sign of a common electronic audience measurement after the launch of TV Markiza in the second half of the nineties. Although the introduction of audience measurement is generally considered a meaningful and profitable, in case the advertising cake reaches almost 100 million viewers, Slovak advertising cake in 1996 did not reach more than one third of this amount $/ \mathbf{1 1} /$. This was not the problem of failure of the first attempt of introducing an electronic audience measurement. Televisions did not make an agreement; therefore, they secured their own research, through diary method. While STV had its own department for this, VTV and Markiza had to obtain it externally. We have already mentioned the negatives of diary measurements; we should also present a different methodology, which was used by both televisions. While daily continual research by STV in the households was based on simple questions, e.g. "have you watched the program ...", Visio agency doing similar studies for Markiza and VTV, required more accurate data and split the broadcasting time into 15minute blocks in which the interviewers specified what they had been watching at exact time of fifteen minutes. It was more difficult for respondents to fill in the form reliably. On the other hand, this research could build more accurate indicator of the audience. Six months after the launch of TV Markiza, STV began doing research using the mentioned method, and only then the public learnt about its biggest fall. The figures after the unified methodology were almost uniform; the variation was $2-4 \%$, which is caused by sympathy and loyalty of the contractor to his client. Big differences were shown in the news programs which is the most lucrative advertising time. Surprisingly, each television reached significantly better results in its own research. Late decision of
STV to use accurate measurement, despite using diary method and forming a stable panel sample which already knew what to do (research was more reliable), resulted in the fact that all media acquired working with the figures published by Visio Agency. Private televisions were the customers and it is clear that they wanted to have research favorable for them. STV, besides the fight for viewers lost the fight for observation and measurement of mood, which also resulted in the loss of important tenths, and perhaps whole percentage points. And talking about the loss of percentage points means tens of millions (Slovak Crowns at that time) losses in the advertising market. The Czech Republic introduced peoplemeters in 1997, which was three years after the launch of the first commercial TV channel. We had not done it for nine years from the beginning of the first private television broadcasting. STV did not need peoplemeters. They did not need to know exactly the fact, that someone else led the market. That would be like putting salt on open wounds. Markiza did not rush to introduce electronic measurement as well. They were satisfied with their dominant position. Two or three percentage points are more worthy than the risk of a possible finding that in fact it would be about five percent less. Other televisions on the Slovak market by 2000 (VTV, TV Luna), having existential problems, had no time, will nor money to think about peoplemeters. Big pressure came after 2001. New televisions on the market, TA3 - a newsformat TV and TV JOJ - a full-format TV, desired to introduce peoplemeters at any costs. Naturally, they needed to know the figures and needed to cut from the growing cake of media market, if they wanted to survive. "According to the General Manager, Martin Lengyel, TA3 diary surveys are simply not relevant, and the clients, who are governed only by them, waste their money because they do not know if they pay effectively for the advertisement."/12/ The shift occurred in 2003. Televisions, after lengthy negotiations in an atmosphere of distrust formed a common company PMT. It made tender for the Contractor of an audience measurement and in the summer of 2004, launched the trial operation. The proper measurements, which results could also see the public came in October of that year. The cost of installing peoplemeters reached approximately 2 million euros. Immediately after publish of the peoplemeters results, journalist Miroslav Sojková from portal HNonline.sk realized a test and compared the 
measurements from the peoplemeters and diary methods at the same period and found differences in the measured values. Data were obtained in the first half of October 2004. Diaries survey added to Markiza 7.77 percent share /13/.Also Jednotka (STV) was previously more of 0.65 percent, TV JOJ was in last printed surveys about 1.99 percent more. From the October audience measurement rise only Dvojka (second channel STV). Electronic measurements showed a 1.98 percent more than it gave by diary survey. An important finding was also the fact that television watched fewer people than the broadcasters thought based on previous diary surveys $/ \mathbf{1 4} /$. While the average number of TV Markiza had a market share ranging from 43 to more than 50 percent $/ \mathbf{1 5}$ /, the first three days of audience measurement by peoplemetres obtained on average 32.9 percent of the total number of active viewers. Markiza was followed by first channel of STV - Jednotka (19.3 percent share) and a private TV JOJ (13.4 percent share) /16/.

\section{Television chess}

Over time, as other private Slovak TV growth, the television market has become a victim of the measurements of an audience. Run after the highest decimal number in the audience and market share leadership has become priority number one for the television management. These factitious phenomenon growths still more. TV`s justify those steps such as action in favor of the audience, because they want to broadcast programs about the viewer desires at a particular time. The truth is, that television's just looking for programs and times, which can attract the most viewers on their screens /17/. Changing programs from day to day, finding the ideal time for the start of the session after every time when did not achieve imagine percentage is becoming common practice. "... The constant changes declining the credibility of the Media (author's note: program periodicals), but ultimately also the broadcaster. Phone calls of angry readers, due to changes in the program can count the thousands, so I'm not sure if frequent changes could not damage television and cannot be a reason of drop the audience ... And if even newspapers could not react to changes in television programs, it is already disquieting."/18/ And if these "tricks" are unsuccessful, TV's do not hesitate to cancel all program or move it to early morning or night hours. Just to be broadcast out of necessity, because money have been invested. If anything proves, the viewer saw a few reruns; usually the first is coming few hours after the premiere, and already in the next day /19/. Television advertising is planned so, that at the moment of the beginning it broadcast, the competition could not start broadcasting the new program because it would be threaten that the viewer has not switch back. Ideally, of course, is if the advertising is in both televisions at the same time. Television Chess are alchemy. The whole media circus that makes for the viewers - to get them to television - has a great paradox. The one who suffers most and is damaged by the television battle is only a viewer. Fixed structure of television broadcasting in Slovakia is practically non-existent. Newspapers with weekly TV Program printed usually week advance increasingly lose their importance. Till the 15:00 the television is uninteresting for the viewer. Management knows this and accordingly deployed and broadcasting. The viewer is at this time by television offered quality unexciting and underestimated. Of course, marketing and economic department wish and argue the opposite, but that is not supported by adequate supply. In the afternoon, already starting mentioned chess with programming and lasts until midnight.

\section{Method attempt - error}

For commercial TV Joj (since 2002) and for public television STV was 20 percent share a magic border on the market up to the year 2008. Who was closer to it, or broke it, won the coveted post second place in the market. Over the years, Markíza (leader of the TV market) set the bar pretty high, and became its slave. The daily number of 40 percent has become imperative not only for day share, but also the lower limit for prime-time. Any value below 35 percent was until recently considered as a flop. The Television newspaper, major television news programs has bigger numbers. At the beginning of 2008 Markíza has 79.7 per cent share of audience, which produced a 32.7 percent market share. Extrapolated to the quantity of recipients, this means 1.5 million viewers $/ 20 /$. TV Markíza was not only dominant, but in prime time rolled the competition. And want to continue. Director of the Centre for Journalism of the most watching television in Slovakia Tibor Búza is clarifying the situation by saying: "What Markiza developed between 19:00 and 19:20 is problem put at risk, other way, for us it is not easy to put at risk JOJand STV News after 19:30. There is a strong habit; the viewer wants to compare the News."/21/ There is only one meaning by those words. Markiza wanted 
increase the dominance after the nineteenth hour, and it was possible at the expense of news STV and TV Joj only, which was broadcast at 19:30. More viewers mean more participation on the market and more advertising potential. As the clear leader of the Slovak television market began to get bored on the throne. The high number of audience in all kinds of programs - and Markíza reached it with third hand serial rerun - really gave it confidence and from this result changes. Television was obviously trying to grab even larger part of the market pie in the most interesting time, which should aim to increase profits and put the competitive Television to the ankles named Markíza. In January the most watched television split its news for two shows. At 19:00 they started News called Headlines and after thirteen minutes, and approximately two-minutes of advertisement - television news continue by part called Today (Before this changes television has generated share nearly to 80 percent after 19:00). Since the beginning of a new issue of TV news reached with Headlines similar numbers (1 378 000 viewers, $77.5 \%$ share). Mathematically Markíza well received as expected./22/

\section{Leader lost the percent's}

Initial positive percent very quickly ran out and started the largest fall of audience by the strongest television on the Slovak market since its inception. Slovak prime time broadcasting was shaken in its foundations. After a few days from start the Headlines viewers leave the program. Forcibly forcing actuality and below-average topics was too strong cup of coffee for viewers, despite the 12 year old habit in this News. Moreover, competition was not sleeping. Slovak Television and TV Joj, from the beginning looking for counter attack and suddenly it pushed into its hands themselves. Catched viewers of Markíza were leaving and searched where to switch their remote. Suddenly, less than a million people looked two new pro- grams. If the Markíza had this number at the beginning of the year, the silver TV logo would be impermissibly blush by this audience. Markíza lost control on the situation. From the planned evolution they made by the method trial - error a Revolution. Against each other. The lowest number from 6 February 2008 says about 819000 viewers and 50.7 percent prime time hour share. Markíza was still a leader, even still the dominant leader in all-day broadcast, but the fall was huge. From that moment the "TV cake" began to share with more equal parts. We can talk about the beginning of the standardization of the television market in Slovakia, but not about its final and enduring form. There was not only fatal mistake in the case of television news change. As Markiza made experiment in this segment, also did it in the purchase of films, serials, licensed programs or production of their own. The second commercial player TV Joj bet on their own production and program stability. Despite of that it's not an example of right TV programming; but changes were not so frequent and so panic than by television leader. TV Joj was able to keep program in broadcasting with not ideal numbers, but in medium-term it turned in favor of television. The viewer rating of TV Markiza steadily declined past for years until it plunged to historic lows. The television news of this TV is no longer most viewed every day. The two on the market, TV Joj is capable defeating Markíza regularly. And it's not only important time for TV when the years established order was changing. "Today is the second month when TV Joj is leader of the market in primetime, so in the most important broadcast TV times. Especially on weekdays we are a leader whole day"/23/, says CEO of the TV Joj František Borovský. Being a leader is important when negotiating about prices./24/ The biggest changes occurred in the past year, what is visible in the table below.

Table no. 2 - year-on-year development of an audience of the two strongest television in Slovakia /25/

\begin{tabular}{|c|c|c|}
\hline All Day 12 to 54 years & february 2011 & january 2012 \\
\hline TV Markíza & $35,4 \%$ & $26,2 \%$ \\
\hline TV Joj & $20,0 \%$ & $22,8 \%$ \\
\hline \multicolumn{3}{|l|}{ Primetime 12 to 54 years } \\
\hline TV Markíza & $41,1 \%$ & $27,3 \%$ \\
\hline TV Joj & $21,6 \%$ & $28,7 \%$ \\
\hline TV News 19-20 hod. & 7. week 2011 & 7. week 2012 \\
\hline TV Markíza & $43,1 \%$ & $35,4 \%$ \\
\hline TV Joj & $27,6 \%$ & $35,5 \%$ \\
\hline
\end{tabular}


Television news of the Markíza are attacked for the nearly eight percent, while TV Joj increased by eight percent, and between the seventh and eighth in the evening has been turns by more people. Markíza was partly weakened by moving news at public STV; it competes directly in broadcasting at 19:30, now. The Digitization /26/ also made changes, it brought the same signal covering in all regions of Slovakia, brought more television and the resulting numbers of audience and market share were diversified between more broadcasters. We dare to say that under the influence of illplanned changes, blind watching of people meters results, proactive steps of competition and all over digitization, the Slovak television market became more realistic and closer to situation what we can traced in Germany today. Although Germany have more nationwide TV stations as Slovakia, but the leader of the day usually achieve less than 20 percent market share./27/

\section{Regularity of the numbers of peoplemeters}

There are many doubts about the credibility of peoplemeters measurement of an audience. The publication of results has become a carefully thought job and encrypted alchemy by press and PR departments of the televisions. Each Television naturally adjusted results according to its image and own needs. The variables in the equation for many unknown are the times of broadcasting, viewers ages, recently we have come to read the numbers of two or more programs at once, because it is more than if we separated them. The battle for every percentage of an audience become sacred, because defending audience means maintain price list of advertising, keep advertisers and therefore profits in millions euros per year. This is not just a symptom of Slovakia. A Simple example from Czech Republic: Private TV Nova has cease to publish statistics in categories D15 + (all viewers over 15 years), and shortened it to viewers 15 to 54 years. Commercial TV needs a younger, productive audience representing purchasing power. In this set of numbers they achieve around 45 percent every evening. In the category of the $\mathrm{D} 15+$ in the top five of prime-time monitoring is mixed and competitive TV stations: Prima Family or public CT1. In the category without an older audience (more than 54) Nova least 2.5 percent better numbers $/ \mathbf{2 8} /$. By the way, since Czech public television CT 1 lost viewers on the first channel in January, so they start published cumulative figures for both channels (CT 1 and CT 2) in February $/ 29 /$. Then the CT has a market share around 21 to 22 percent instead of 17 or 18 percent. In Slovakia, from first February 2010 they increased panel of households from the original number of 800 to 1,200, representing approximately 3,600 individuals. Peoplemeters also started to use Audio Matching technology, which allows measurement of all forms of digital signal /30/. Slovak peoplemeters are one of the best which are available to measure audience in Europe. Nevertheless, televisions behave childishly in processing and evaluating of the results. "Instead of holding longerterm concept and program strategies respond by a single criterion - the actual number of audience and market share in biggest target groups. The result of this process are three television focused on the same group of people, essentially, to all viewers over the age of twelve years whose are willing to look Slovak TV stations. At the moment, when the title don't get at least average level of the stations, television managements start immediately think how to change it, even if not cancel." /31/ This phenomenon, together with an excessive number of reruns is currently characteristic for the development of Slovak Television. The victim of this "earn easy money" system has become only Markíza, who lost the crown of elusive leader. What will be the next reactions of viewers for television audience measurement obsession, low bid of premiere, frequent changes in programs and constantly recycling and regenerating the same formats is difficult to predict. For Televisions are important just profit and development in this area does not change dramatically. Despite the growing influence and market space for internet, according to these numbers television is not threatened. The viewer is simply difficult separable from television and remains there despite above described situation. Until it does so, we will have to write about his captivity and domination meters above man - the TV viewer.

Notes

/1/ http://www.sme.sk/c/2979235/tv-vysielanie-naslovensku-slavi-polstorocie.html\#ixzz11bgcLdza, 8 . 4. 2012

/2/ According to research conducted in 2011 at the Catholic University, formed a foreign film production in broadcasting of Slovak televisions from $88 \%$ to $100 \%$. 
/3/ Darmo, J. (1996). Slovenská televízia, Fakty 1956 1996. Bratislava: Slovenská televízia, s. 42

/4/ From June 1991 to June 1992 broadcast on Slovakia television TA3, which was commercially tuned third range of public television - STV. For lack of funds the broadcast was stopped after one year.

/5/ Mistrikova, Z. (2001). Zmeček, A. a kol.: Mediálna ročenka 1990 - 2000, Mediálny inštitút, s. 171 http://www.mi.sk/medialna\%20rocenka/173/172_file s/image002.gif, (8. 4. 2012)

/6/ Czechoslovak Television while being dissolved of the law adopted by the Federal Assembly of Czechoslovakia in the years between 1953 to 1992 the central eleven directors.

/7/ Markiza audience reached high numbers in the years 1996 - 2000 with shows like Dynasty, Dallas, Step by step, Alf, MacGyver, Baywatch or the Police Academy series, Star Trek, Naked Gun and Indiana Jones.

/8/ Mistrikova, Z.; Zmeček, A. a kol.: Mediálna ročenka 1990 - 2000, Mediálny inštitút, 2001, s. 38 http://www.mi.sk/medialna\%20rocenka/173/172_file s/image002.gif, (8.4. 2012)

19/ Mistrikova, Z.; Zmeček, A. a kol.: Mediálna ročenka 1990 - 2000, Mediálny inštitút, 2001, s. 40 http://www.mi.sk/medialna\%20rocenka/173/172_file s/image002.gif, (8. 4. 2012)

/10/ Mistrikova, Z.; Zmeček, A. a kol.: Mediálna ročenka 1990 - 2000, Mediálny inštitút, 2001, s. 38 http://www.mi.sk/medialna\%20rocenka/173/172_f iles/image002.gif, (8. 4. 2012)

/11/ Mistrikova, Z. (2001). Zmeček, A. a kol.: Mediálna ročenka 1990 - 2000, Mediálny inštitút, s. 38 http://www.mi.sk/medialna\%20rocenka/173/172_f iles/image002.gif, (8. 4. 2012)

/12/ Anonym: Pôrodné bolesti slovenských peoplemetrov. [cit. 2012-01-08]. Dostupné na internete: $<$ http://www.radiotv.cz/p_tv/t_obchod/prodnebolesti-slovenskych-peoplemetrov/>.

/13/ Market share of all television viewers, who watched television exactly on that time.

/14/ Sojkova. M.: Peoplemetre -tabul'ka Porovnanie priemernej sledovanosti televízií. [online]. In: hnonline.sk, 19. október 2004. [cit. 2012-04-06]. Dostupné na internete: < http://hnonline.sk/c122136945-peoplemetre-tabulka-porovnaniepriemernej-sledovanosti-televizii>.

/15/ Horobova, M.: Každá televízia vidí svoju sledovanost' inak. [online]. In: sme.sk, 15. marec 2002. [cit. 201204-08]. Dostupné na internete: <http://www.sme.sk/c/269307/kazda-televizia-vidisvoju-sledovanost-inak.html/>.
/16/ Sojkova. M.: Najoyššiu sledovanost’ má spravodajstvo. [online]. In: hnonline.sk, 19. október 2004. [cit. 201204-06]. Dostupné na internete: $<$ http://hnonline.sk/c1-22136975-najvyssiusledovanost-ma-spravodajstvo>.

117/ The research about filling program of the Slovak Television in 2011 reveals, that Slovak Television broadcast together on average just $11 \%$ premiere movies.

/18/ Krasko, I.: TV program: zmena za zmenou, IN: Stratégie: Média 2010, Bratislava, č. 6, roč. 20, s. 15

/19/ A dangerous phenomenon has become the endless repetition of films that television has often repeated the same day and almost always one more time during the week in which it aired. For example, research from December 2011 says, that from 55 films broadcast in the Christmas week on TV JOJ, was 47 repetitions. Thirteen of it was repeated in the month, five of them have been repeated on the same day.

/20/ http://medialne.etrend.sk/televizia/grafy-atabulky.php?medium=televizia\&co=vyvojrelacii $(8$. 1. 2012)

/21/ http://medialne.etrend.sk/televizia/grafy-atabulky.php?medium=televizia\&co=vyvojrelacii $\quad(7$. 12. 2007)

/22/ Kravčak, P. (2008). Nový impulz pre televízny trh na Slovensku In: Nové horizonty, roč. II. č. 2, s. 12

/23/

http://medialne.etrend.sk/televizia/sprava.php?spra $\mathrm{va}=6272$ (7. 2. 2008)

/24/ Trško, M. (2012). Markíza už nie je suverénna. In: SME, 27. 2. 2012, roč. 20. č. 48 , s. 1

/25/ Trško, M. (2012) Markíza už nie je suverénna. In: SME, 27. 2. 2012, roč. 20. č. 48 , s. 1

/26/ The Digitalisation in Slovakia was in the years 2010 and 2011.

/27/ RTL (17,3\%), ProSieben (10,8 \%), Sat.1 (10,6 \%), Vox $(7,4 \%)$, ARD (7,2 \%), ZDF (6,4\%), RTL II $(6,3$ $\%)$ Kabel $1 \quad(5,9 \quad \%), \quad$ Zdroj: http://medialne.etrend.sk/televizia-spravy/ani-sat1sa-nemusi-vydarit-novy-serial-sledovanost-vnemecku-.html (20.1.2010)

/28/http://www.ato.cz/vysledky/tydenni-data/share/1554 (31. 3. 2012)

/29/http://www.digizone.cz/clanky/carovani-s-cisly-zpeoplemetru-uz-i-ceska-televize/ (12. 3. 2012)

/30/http://medialne.etrend.sk/televiziaspravy/sledovanost-stv-je-uz-uplne-neznama-ocitlasa-v-baliku-ostatnych.html (15. 4. 2012)

/31/http://medialne.etrend.sk/televizia-clanky/media2005-ani-velke-televizie-nemozu-byt-prevsetkych.html (15. $\quad 4$. 2012) 


\title{
TELEVIZIJSKO TRŽIŠTE I GLEDATELJSKA PUBLIKA U SLOVAČKOJ
}

\author{
Peter Kravcak \\ Katoličko sveučilište u Ruzomberoku, Ruzomberok, Slovačka
}

\begin{abstract}
Sažetak
$\mathrm{U}$ ranim devedesetim godinama dvostruki prijenosni sustav $u$ mladoj državi $u$ srcu Europe omogućio je razvitak emitiranja televizijskih programa na razinikoju gledatelji do tada nisu mogli ni sanjati. Komercijalno emitiranje televizijskog programa prevladalo je u pet i pol milijunskoj zemlji. Privatno emitiranje steklo je nadmoć nad više od četrdeset godina starim državnim TV emitiranjem koje je poslano na statističke margine. Povjerenje prema prvoj - i kasnije drugim privatnim televizijama - raslo je brže od broja publike. Ravnatelji s utjecajem na zakonodavce, menadžeri su koji određuju vrijeme prijenosa programa iz tjedna u tjedan. To je nazvano kao pronalaženje optimalnog vremena temeljenog na željama publike. Rezultat je današnji veliki kaos televizije za gledatelje, koji , radi nepredvidljivih promjena u emitiranju televizijskog programa prestaju biti zainteresirani. Već dugi niz godina najgledaniji kanal je pao na razinu podcijenjenog rivala i radi panike, počeli su raditi još više fatalnih promjena. Sve u ime publike $i$ izvrsnih koje daju tzv. People-metri. S istim problemom se također sučeljavaju i druge post-komunističke zemlje, kao npr. drugi dio bivše Čehoslovačke, Češka Republika. Rad se usredotočuje na analizu i evaluaciju slovačke televizije sfere (dijelom u odnosu na češku televiziju), koja čini se, nakon dvadeset godina dualnog emitiranja, okuplja pravu medijsku konkurenciju. No, ne sviđa se to svima.
\end{abstract}

\section{Ključne riječi}

Tv tržište, gledatelji, emitiranje 